\title{
Ukládání správních trestů za účinnosti nové právní úpravy (nejen na př́kladu přitěžujících a polehčujících okolností)
}

\author{
Imposing of Administrative Sanctions According \\ to New Czech Legal Regulation (Ilustrated by Example \\ Aggravating and Attenuating Circumstances etc.)
}

\author{
Nikola Jílková*
}

\begin{abstract}
Abstrakt
Pro veréjnou správu, v podminkách právního státu, je nezbytné zajistit relativně volnè určenou obsahovou stánku jejího výkonu, aby mobla pružně zajištovat realizaci moci exekutivní. K zajišténí jejího chodu je verejná správa nadána mj. oprávnèním trestat (rozhodovat o vinè a trestu za správni delikety) a s tímto souvisí uváženi správního orgánu o spravedlivém a priměreném správnim trestu, tedy o volbè jeho drubu a výmèry. Vedle zásady zákonnosti je jednim ze stěžejnich principù pri správnim uváženi princip primèrenosti, keterý dává rámec správním orgánuim pri stanovováni drubu a výméry správnich trestü. Autorka se proto věnuje $v$ textu tomuto principu, nebot' dává limity správnim orgánům v jejich správním uvážení.

Mezi základni kritéria napomáhajici ukládat primérený správni trest vedle určení povahy a závažnosti pře-

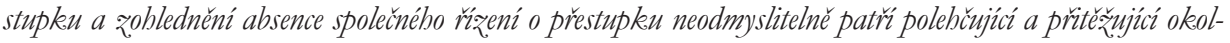
nosti ${ }^{1}$ puisobici jako voditko pro správné a spravedlivé uř́eni správního trestu. Autorka nejdrive poukáže na aktuálni postaveni správního trestáni v $C^{C} R$ a v této souvislosti se zaměrí na problematiku ukládáni

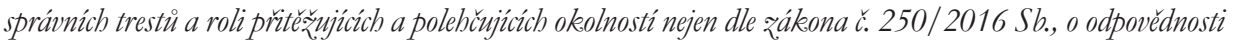
za prestupky a řrzeni o nich, ale i v judikature správnich soudu. Tento prìspèvek si neklade za cíl suplovat roli komentáru k prestupkovému zákonu. Zejména z divodu rozsabu se proto nevènuje každé jednotlivé okolnosti zulást', ale spíse se snaži poukázat na nèkteré dalši závéry vyplývajici zodborné literatury, nebo z judikatury.
\end{abstract}

Klíčová slova

Správni trestáni; reforma správního trestáni; nový prestupkový zákon; správní trest; správni uváženi; princip primèrenosti; kritéria pro ukládáni správnich trestů; prítéžujici okolnosti; polebüujici okolnosti.

\section{Abstract}

For public administration, under the terms of the rule of law, there is necessary to provide a relatively freely determined content for flexibly exercise of executive power. Public administration has power to punish (to decide on guilt and punishment for administrative offenses) to provide regular functioning. This power is related

\footnotetext{
* Mgr. Nikola Jílková, doktorandka, Katedra správní vědy a správního práva, Právnická fakulta, Masarykova univerzita, Brno / Ph.D. student, Department of Administrative Studies and Administrative Law, Faculty of Law, Masaryk University, Brno, Czech Republic / E-mail: jilkova.n@mail.muni.cz

1 Tato kritéria společně s dalšími upravuje pro ukládání správních trestů za přestupky zákon v \37 a násl. zákona č. 250/2016 sb., o odpovědnosti za přestupky a řízení o nich. Pro trestné činy je upravuje \39 zákona č. 40/2009 Sb., trestní zákoník nebo \14 zákona č. 418/2011 Sb., o trestní odpovědností právnických osob, přičemž uvedená kritéria jsou stěžejní z hlediska uložení př̀iměreného a individualizovaného trestu pro pachatele.
} 
to the discretion of the administrative authority about a fair and proportionate administrative sanction, ie the choice of its type and limit. In addition to the principle of legality, the principle of proportionality is one of the key principles in administrative discretion, which provides a framework. for administrative authorities.

Among the basic criteria which help to impose a proportionate administrative sanction, there are inevitably mitigating and aggravating circumstances that serve as a guideline for the correct and equitable determination of administrative sanction. The author will first focus on the current position of administrative punishment in the Czech Republic and in this context will focus on the issue of administrative sanction and the role of aggravating and attenuating circumstances according to the Act No. 250/2016 Coll., On the liability for offenses and the proceedings about them, case law of the administrative courts. This post does not aim to supplement the role of commentaries on minor crimes. In particular, it does not deal with each individual circumstance separately, but focus on some other conclusions resulting from literature or case law.

\section{Keywords}

The Administrative Punishment; The Reform of an Administrative Punishment; The Administrative Punishment; The Administrative Discretion; The Principle of Proportionality; The Criteria's for Imposing Administrative Sanctions; The Aggravating Circumstances; The Mitigating Circumstances.

\section{Úvod do správního trestání v ČR}

Procesní i hmotněprávní úprava správních deliktů zaznamenala velkých změn zejména přijetím zákona č. 250/2016 Sb., o odpovědnosti za přestupky a řízení o nich (dále též „PZ“ či „přestupkový zákon“). Zákonodárce tak reagoval na dlouhodobě problematickou situaci zejména v otázce absence potřebné právní úpravy správních deliktu právnických a fyzických podnikajících osob, která především po stránce hmotněprávní byla nedostatečná. Situace byla o to vyostřenější, nebot’ správní orgán ukládající sankce² disponuje často nástroji umožňující významný zásah do subjektivních práv jednotlivce. Častým př́kladem toho jsou pokuty, jejichž horní hranice dosahují v zákonech mnoha milionových částek, u kterých je nutné správní trest řádně zvážit mj. tak, aby nemohl mít pro pachatele nežádoucí likvidační charakter. Široké rozpětí správního uvážení, které nezřídka začíná na nulové dolní hranici a končí na hranici v řádech desítek nebo stovek milionů, ${ }^{3}$ navíc při časté absenci kritérií pro jejich ukládání v zákonech, dlouhodobě neprrispívalo ani právní jistotě a bylo často těžištěm oprávněné kritiky. Správní orgány

2 Pojem sankce byl od účinnosti přestupkového zákona nahrazen pojmem správní trest, kdy cílem této změny bylo sjednotit zákonnou terminologii s terminologii doktrinální. Důvodová zpráva $\mathrm{k}$ tomuto uvedla, že pojem správní trest „vhodněji vyjadruje trestni povahu hrozici a ukládané sankce. "In: Vládní návrh zákona o odpovědnosti za přestupky a řízení o nich včetně důvodové zprávy. Sněmovní tisk 555/0, část č. 1/2. Poslanecká snèmovna Parlamentu Ceské republiky [online]. 2015, s. 166 [cit. 16.3.2018]. Dostupné z: http://www.psp.cz/sqw/text/tiskt.sqw?o=7 \& ct=555 \& ct1=0 (dále též „důvodová zpráva k PZ“).

3 Srovnej např́klad zákon č. 185/2001 Sb., o odpadech a změně některých dalších zákonů, kde horní hranice dosahuje částky 50 milionů korun; nebo \ 91 a násl. zákona č. 458/2000 Sb. energetický zákon, kde horní sazba ukládané pokuty dané horní hranicí 50 milionů korun, může být prolomena uvážením správního orgánu o uložení pokuty ve výši 1 \% z čistého obratu dosaženého držitelem licence za poslední ukončené účetní období. 
se tak častěji uchylovaly k ukládání pokut při dolní hranici sazby, resp. ne vždy využívaly celé rozpětí sazby u pokut, a to i z důvodu, že takový trest nebýval správními soudy posuzován jako nepř́měřený. ${ }^{4}$

Silný vliv na současnou i budoucí podobu trestání má bezesporu i extenzivní výklad čl. 6 EÚLP ${ }^{5}$, který, dle mého názoru, ještě více přibližuje soudní a správní trestání, což je bezpochyby patrné i v novém přestupkovém zákoně, kde se zákonodárce velkou měrou inspiroval v hmotněprávní i procesní úpravě trestního práva. Současně principy trestního práva ${ }^{6}$ vedle dalších principů aplikovatelných pro správní trestání jsou dlouhodobě důležitým vodítkem pro práci správních soudů a správních orgánů. V minulosti tyto principy pomáhaly tvořit základní rámec správního uvážení tam, kde chyběla potřebná právní úprava a staly se tak významnou součástí pramenů správního trestání. V tomto směru je zajímavé posouzení vztahu obecných principů a volného uvážení správního orgánů, kdy právní principy vtělené do ustanovení zákona je nutné posuzovat jako zákonná kritéria při ukládání trestu, kterými je správní orgán ve svém volném uvážení limitován a vázán.

Uvedené aspekty, jakož i silící hlasy kritizující neúnosnou situaci, vedly k dlouhodobým snahám o komplexní uchopení správního trestání a vyústily vedle přijetí zmíněného přestupkového zákona, dále k přijetí zákona č. 251/2016 Sb., o některých přestupcích, a rovněž doprovodného změnového zákona č. 183/2017 Sb., a to vše s účinností od 1. 7.2017.

\section{Obecně k ukládání správního trestu}

Správní tresty společně s ochrannými opatřeními představují právní reakci státu za spáchaný správní delikt, jejichž nejobecnějším účelem je ochrana společnosti. I přes fakt, že dnes je trestání neodmyslitelně spjato s výkonem veřejné správy, nesmíme zapomínat, že obecně nepatří mezi originální funkce veřejné správy ${ }^{8}$, těmi ,je funkece zajištovací, ochranná, spočivajici ve vytváreni podminek pro udržováni veřejného porádku a puisobeni ve prospěch

4 V této souvislosti se nabízí poukázat na rozsudek Nejvyššího správního soudu ze dne 21. 8. 2003, sp. zn. 6 A 96/2000, na který správní soudy dnes poukazují a kterým bylo dovozeno, že sankce při samé dolní hranici sazby nedosahuje zpravidla nepřiměřené výše. Obdobně rozsudek Nejvyššího správního soudu ze dne 27. 9. 2016, č.j. 5 As 36/2016-30.

5 Stěžejní je obecně známé rozhodnutí Evropského soudu pro lidská práva ze dne 8. 7. 1976, stížnost č. 5100/71. Věc Engel a ostatni proti Nižožemí.

6 Judikatura opakovaně dovodila, že pro správní trestání platí obdobné principy jako pro trestání soudní, a v řízení o přestupku je na místě analogicky aplikovat pravidla stanovená trestním právem, pokud samotný předpis správního práva vůbec neřeší spornou otázku a analogie není k újmě účastníka řízení." Rozsudek Nejvyššího správního soudu ze dne 22. 1. 2009, č. j. 1 As 96/2008-115.

7 Srovnej přiměřeně JELÍNEK, J. a kol. Trestníprávo bmotné. Obecná část. Zvlástni část. 6. aktualizované a doplněné vyd. Praha: Leges, 2017, s. 427.

8 Shodně Martin Kopecký, který upřesňuje, že „posuzováni viny a ukládáni trestů za protiprávni činy správnimi orgány lze považovat za výjimku zpravidla, že výkon trestnípravomoci náleží souduim“. In: KOPECKÝ, M. Př́slušnost v rízeni o prestupcích. ASPI, 2018. Dostupné v právním systému ASPI [cit. 16. 3. 2018]. 
minimalizace protiprávni cinnosti " Jednou z forem realizace správního trestání je potom vlastní ukládání správního trestu za správní delikt.

Při ukládání správního trestu je nutné dbát na to, aby byl zajištěn požadavek subsidiarity trestní represe a účel trestu. V této souvislosti uvedl Ústavní soud, že smyslem a účelem trestu $v$ nejobecnější rovině je ochrana společnosti a nemá jim být žádný jiný záměr. ${ }^{10}$ Z uvedeného plyne, že trest nesmí být prostředkem pro řešení jiných společenských problémů. Jedině individualizovaný a zákonný trest v sobě spojuje jak individuální represi a prevenci vůči pachateli, tak i potřebnost výchovného působení na ostatní členy společnosti (tzv. generální prevence). Prevenci a represi je třeba chápat vyváženě v každém individuálním př́ípadě, nebot' pouze potom může individuální prevence působit jako nástroj prevence generální. ${ }^{11}$

Proces ukládání správního trestu a proces volby jeho druhu a výměry v mezích zákonem dovolených hranic bývá častým příkladem správního uvážení ${ }^{12}$ správního orgánu. Nejedná se o zcela volnou úvahu, ba naopak „správni uváženi nemá vykazovat znaky libovile, musi být rádnè odìvodnèno a výstup uplatnèné diskrečni pravomoci správního orgánu musi být v kontextu a ve vątahu logickébo vyplýváni se skutkovými okolnostmi, které daný př́pad individualizuji. To ostatnè vyplývá rovněz. z. ustanoveni $\int 2$ odst. 4 správníbo rádu. Správni orgán dbá, aby prijaté réseni bylo v souladu s veréjným zájmem a aby odpovidalo okolnostem daného prípadu, jakož i na to, aby prí rozhodováni skutkově shodných nebo podobných prípadi nevanikaly nedivodné rozdíly. $Z$ toho plyne, že každé správni uváženi má své mezue. "13

Z hlediska rekodifikace stojí za zmínku, že se zákonodárce velmi inspiroval v zákoně č. 40/2009 Sb. trestním zákoníku (dále též „TZ“) a při začlenění nových institutů do přestupkového zákona ${ }^{14}$ přistoupil ke změně formulace. Předchozí právní úprava přestupků používala dikci, kdy správní orgán „uložil““ sankci. Účinností PZ došlo ke změně formulace na „lze uložit“ správní trest. Změna tohoto znění u sankčních norem na první pohled naznačuje fakultativnost uložení uvedeného správního trestu ze strany správního orgánu. Nejedná se ale o neomezené rozšíření uvážení správního orgánu, zda správní trest uloží, jež by mohlo hraničit s libovưlí. I přes uvedenou dikci je správní orgán nadále

9 KLÍMA, K. a kol. Odpovédnost verégné moci. Praha: METROPOLITAN UNIVERSITY PRAGUE PRESS, 2013, s. 217.

10 Uvedený judikát se týká soudních trestů, je ale plně použitelný i pro účely správních trestů. Srovnej nález Ústavního soudu ze dne 23. 4. 1998, sp.zn. IV. ÚS 463/97.

11 Ibid.

12 Správní uvážení spojujeme s procesem rozhodování veřejné správy, kdy veřejná správa si sama volí prostředky, kterými naplňuje své funkce, přičemž její snahou je vždy nalezení adekvátního a účelného řešení. Srovnej: SKULOVÁ, S. Správni wáǎ̌ení - základní charakteristika a sowvislosti pojmu. Brno: Masarykova univerzita, 2004, s. 40.

13 Rozsudek Krajského soudu v Brně ze dne 11. 1. 2017, č. j. 31 A 72/2015-96.

14 Zejména podmíněného upuštění od uložení správního trestu dle $₫ 42 \mathrm{PZ}$, upuštění od uložení správního trestu dle $₫ 43 \mathrm{PZ}$, mimořádného snížení výměry pokuty dle $\$ 44 \mathrm{PZ}$. 
povinen postupovat $\mathrm{v}$ souladu se zákonem, resp. zjistí-li spáchání přestupku a nebude-li dána ze zákona možnost odklonu, bude nadále povinen k uložení správního trestu za přestupek.

\section{Princip přiměřenosti správního trestu}

Vedle principů zákonnosti a individualizace správního trestu, které jsou zpravidla v judikatuře zdůrazňovány ${ }^{15}$, hrají při ukládání správních trestů významnou roli právní principy a zejména i princip přiměřenosti, resp. proporcionality ${ }^{16}$. I přes to, že požadavek na ukládání přiměřených správních trestů v PZ obdobně jako je tomu v \38 trestního zákoníku ${ }^{17}$, není výslovně uveden, je třeba jej zvažovat i při aplikaci správních trestů, nebot' vyplývá z celé koncepce hledisek pro výměru trestu. „Právni význam principu proporcionality tkevi v tom, že slouři jako voditko v prípadè, kdy verejná správa v rámci výkonu své pravomoci zasahuje do subjektivního práva nebo svobody soukromé osoby. "18 A rovněž nepř́mo pomáhá vyjasnit rozumnou a ospravedlnitelnou míru zásahu veřejné moci podmíněné veřejným zájmem. ${ }^{19}$

V českém právním prostředí se k vymezení proporcionality vyjádřil mj. i Ústavní soud, který ve své judikatuře uvádí, že princip proporcionality: „zejména predpokládá, že opatreni omezujici základni práva či svobody nesmi svými negativnimi dìsledky presábnout klady, keteré predstavije veřjný zájem na těchto opatreních." ${ }^{20}$ Samotná přiměřenost se ve správním řízení dovozuje mj. i z \ 2 odst. 4 správního řádu, ${ }^{21}$ dále ji lze neprúmo dovodit z \ 78 odst. 2 ve spojení s \ 65 odst. 3 zákona č. 150/2002 Sb. soudního řádu správního (dále též „s.ř.s.“) zakládající moderační právo soudu při zjevné nepřiměřenosti trestu, a především v ustanoveních přestupkového zákona ${ }^{22}$.

Ve správním trestání, obdobně jako je tomu v trestání soudním, je princip proporcionality při ukládání trestů ohraničením přípustné intenzity zásahu státu do práv jednotlivce.

15 Srovnej např. rozsudek Nejvyššího správního soudu ze dne 30. 9. 2010, č. j. 7 As 71/2010-97, či rozsudek Nejvyššího správního soudu ze dne 12. 4. 2017, sp. zn. 5 As 152/2016.

16 Termín proporcionalita vychází z latinského spojení „pro portio“, jež má znamenat vztah mezi dvěma či více prvky. Smyslem principu proporcionality je hledání spravedlivé rovnováhy mezi cílem a použitými prostředky při střetu mezi soukromými a veřejnými zájmy.

17 Srovnej \ 38 TZ „Primérenost trestnich sankeci: (1) Trestni sankece je nutno ukládat s prïhlédnutím ke povaze a závažnosti spáchanébo trestnébo činu a pomèrim pachatele. (2) Tam, kde postači uloženi trestni sankece pachatele ménè postibujici, nesmi být uložena trestni sankece pro pachatele citelnèjši. (3) Př ukiádáni trestnich sankeci se prỉblédne i k právem chránéným zájmùm osob poškozených trestným čnem. "

18 KOŠIČIAROVÁ, S. Principy dobrej verejnej správy a Rada Európy. Iura Edition, 2012, Právna monografia, s. 33 a 34.

19 Ibid.

20 Nález pléna Ústavního soudu ČR ze dne 15. 11. 2011, sp. zn. Pl. ÚS 20/09.

21 „Správni orgán dbá, aby prijaté rěseni bylo v souladu s verejným zájmem a aby odpovídalo okolnostem danébo prípadu, jakož i na to, aby prí rozhodováni skutkově shodných nebo podobných prīpadui nevanikaly nedivodné rozdily. "

22 Srovnej např. \37 až 41, 』44 odst. 1 písm. c), \50/1, 84 odst. 1 či \ 87 odst. 2 PZ. 
Proporcionalita přitom není významná pouze z hlediska samotného ukládání správního trestu jako činnosti správního orgánu, ale odehrává se i v dalších rovinách. Jednou rovinou je požadavek, aby zákonem stanovené správní tresty mohly být v konečném důsledku přiměřené, tzn. aby dávaly správnímu orgánu možnost zohlednit specifika prípadu tak, aby uložený trest nebyl pro pachatele likvidační. ${ }^{23} \mathrm{~V}$ této souvislosti má význam i judikatura Ústavního soudu, která se v nejednom př́padě vyjádřila k dolní hranici pokuty a její slučitelnosti s principy právního státu, kdy z této judikatury vyplývá, že limitace uvážení správního orgánu stanovením spodní hranice pokut v zákoně má sledovat legitimní cíl, nebot' zřetelnějším zpơsobem umožňuje odlišit závažnost či nebezpečnost těch kterých typů protiprávního jednání. Nelze však vytvářet takové spodní hranice, které neumožňují individualizaci trestu, resp. přihlédnutí k majetkovým poměrům pachatele. ${ }^{24}$

Druhou rovinou přiměřenosti trestu je vlastní požadavek na činnost správního orgánu vyjádřený mj. v zásadách činnosti veřejné správy v \ 2 odst. 3 SŘ, kdy i při ukládání správního trestu se správní orgán pohybuje v mezích stanovených zákonem a šetří práva nabytá v dobré víre, jakož i oprávněné zájmy osob, jichž se činnost správního orgánu $\mathrm{v}$ jednotlivém př́padě dotýká, kdy může zasahovat do těchto práv jen v nezbytném rozsahu. Př́ ukládání trestu je správní orgán povinen obecně k individualizaci uloženého trestu ve vztahu k osobě pachatele a závažnosti spáchaného správního deliktu při současném zohlednění své předchozí rozhodovací praxe. ${ }^{25}$ Nejvyšší správní soud prritom rozšíril povinnost individualizace trestu o obecný požadavek ,prĭhlédnout k osobním a majetkovým pomèrùm pachatele tehdy, pokud je podle osoby pachatele a výse pokuty, kterou lze uložit, žrejmé, že by pokuta mobla mit likvidačni charakter, a to i v prĭpadech, kedy prǐslušný zákon osobni a majetkové poméry pachatele v taxativnim výctu bledisek rozhodných pro určeni výse pokuty neuvádí. "26

Třetí rovinou je možnost následné kontroly přiměřenosti uloženého trestu ze strany správních soudů. Nepřiměřenost ukládaných správních trestů lze považovat za jeden z projevi̊ nesprávného výkonu veřejné správy $\mathrm{v}$ oblasti správního trestaní. ${ }^{27}$ Zde je nutné zdůraznit, že ale ne každá nepřiměřenost bude významná z hlediska soudní kontroly. Tou bude pouze nepřiměřenost kvalifikovaná, dosahující bud’ ústavní dimenze,

23 K zákazu ukládání likvidačních sankcí srovnej obecně známý nález pléna Ústavního soudu ze dne 13. 8. 2002, sp. zn. Pl. ÚS 03/02. Uvedenou judikaturu částečně relativizoval ve správním soudnictví rozšířený senát Nejvyššího správního soudu, který v usnesení ze dne 20. 4. 2010, č. j. 1 As 9/2008-133, dospěl k závěru, že ukládání likvidačních pokut v řízeních o správním deliktu možné je výjimečně za určitých okolností, přičemž definoval i př́pustnou výjimku z uvedeného zákazu.

24 Ibid.

25 Nejvyšší správní soud zde uvedl, že „správni orgán svou rozhodovaci praxí svému uváženi sám stanovi určité meze a musi být schopen souladnost své roz̧hodovaci činnosti pred soudem obhájit. "In: rozsudek Nejvyššího správního soudu ze dne 14. 2. 2014, č. j. 4 Ads 118//2013-33.

26 Usnesení Nejvyššího správního soudu ze dne 20. 4. 2010, sp. zn. 1 As 9/2008.

27 Řadí se sem vedle úplné absence postihování protiprávních jednání, selektivnosti správního postihu, nebo porušování základních principu správního trestání. Srovnej: KLÍMA, K. a kol. Odpovědnost verejné moci. Praha: METROPOLITAN UNIVERSITY PRAGUE PRESS, 2013, s. 217. 
nezákonnosti, nebo v ojedinělých případech zjevné nepřiměřenosti. Soudní kontrola přiměřenosti je omezena na ty př́pady, pokud nepřiměřenost uloženého trestu dosahuje míry nezákonnosti (a to může být i s přihlédnutím k odchylce od předchozí rozhodovací praxe správních orgánů), nebo v př́padech, kdy trest není sice nezákonný, ale s ohledem na okolnosti př́padu je zjevně neprriměřený, pak správní soudy za podmínek stanovených v $\int 78$ odst. 2 s.řr.s. ${ }^{28}$ mohou př́stoupit k moderaci správního trestu.

Princip přiměřenosti trestu, stejně jako další principy trestního práva nullum crimen sine lege, nulla poena sine lege, subsidiarity trestní represe, zásady personality trestů, byly primárně formulovány pro oblast trestního práva, nelze je ale opomíjet ani ve správním trestání, a to s odkazem na záruky spravedlivého procesu, jež jsou koncipovány v ústavním pořádku a zavazují tak nejenom soudy, ale i správní orgány. ${ }^{29}$

\section{Kritéria pro ukládání správního trestu dle $\$ 37$ PZ}

Jak již bylo uvedeno, z hlediska zásady individualizace má pro naplnění účelu trestu rozhodující význam přiměřenost trestu, jejíž požadavek vyplývá ze zákona a kterými jsou dle ustanovení \37 PZ:

- Povaha a závažnost spáchaného přestupku pro společnost,

- Absence rozhodnutí o jednom nebo více přestupků spáchaných jedním skutkem ve společném řízení

- Přitěžující a polehčující okolnosti

- U pokusu míra přiblížení k dokonání přestupku a k okolnostem a důvodům, pro které k dokonání nedošlo

- U spolupachatelů míra jednání každého

- U fyzické osoby k osobním poměrům

- U právnické osoby k povaze její činnosti

- U právního nástupce rozsah, v jakém na něj přešly výnosy, užitky a jiné výhody, či zda pokračuje v činnosti

- Retroaktivita ve prospěch pachatele u pokračujícího, trvajícího nebo hromadného přestupku

28 Jednou z podmínek pro jeho aplikaci je zjevná nepřiměřenost trestu, který nelze kvalifikovat jako nezákonný, ale ve vztahu závažnosti přestupku a osobě pachatele je zjevně nepřiměřený. Zjevná nepřiměřenost je brána jako kvalifikovaná forma nepřiměřenosti. Zde je nutné zdůraznit, že se jedná o výjimečné oprávnění, kdy v posledních dvou letech nebylo vyhověno žádnému návrhu na moderaci, zejména s odůvodněním nesplnění podmínky zjevné nepřiměřenosti.

$29 \mathrm{~V}$ této souvislosti srovnej ustálenou judikaturu, podle které „trestnost správních deliktui se ř́dí obdobnými principy jako trestnost trestných činu. Je proto napr. vyloučen soubèh správnich deliktui tam, kede se jedná o pokračujucí, hromadný nebo trvajici delikt, pro trestnost jednáni musi být naplnèna i materiálni stránka deliktu a krajní nouze je stavem vylučujicím protiprávnost jednáni naplnumicího formálni znaky deliktu. "Rozsudek Nejvyššího správního soudu ze dne 31. 05. 2007, č.j. 8 As 17/2007. 
Obecná hlediska pro posouzení povahy a závažnosti spáchaného správního deliktu stanoví přestupkový zákon v \38. Jedná se přitom o základní kritérium pro ukládání trestu. ${ }^{30} \mathrm{~V}$ právní úpravě obsažené v ustanovení \ 37 písm. c) PZ dochází k výslovnému oddělování přitěžujících a polehčujících okolnosti od povahy a závažnosti přestupku upravené v \37 písm. a) PZ. Tímto systémovým oddělením přitěžujících a polehčujících okolností zákonodárce vytváří otázku, jaký je vztah mezi okolnostmi spáchání přestupku dle $\int 38$ písm. d) PZ, které určují povahu a závažnost přestupku a přitěžujícími a polehčujícími okolnostmi dle \ 39-40 PZ.

Dle mého názoru je nutné posuzovat okolnosti spáchání přestupku dle \ 38 písm. d) PZ jako jedno z kritérií určení povahy a závažnosti přestupku odděleně od přitěžujících a polehčujících okolností dle \37 písm. c). Okolnosti přestupku, které jsou zákonným znakem přestupku, nebo které budou zohledněny při určení povahy a závažnosti přestupku, již nemohou být znovu posuzovány jako prìtěžující a polehčující kritérium. Na druhou stranu zákon ve výčtu přitěžujících a polehčujících okolností uvádí i takové okolnosti, které by bylo možné posoudit jako okolnosti spáchání přestupku (např. spáchání pod vlivem hrozby nebo nátlaku). Odborná literatura k okolnostem spáchání přestupku uvádí, že se jedná o okolnosti, které zvyšují nebo snižují závažnost přestupku, např́lklad závažnost přestupku může snižovat skutečnost, že pachatel fyzická osoba spáchal přestupek pod vlivem tíživých osobních nebo rodinných poměrů, z existenčních důvodů, pod vlivem jiné osoby. $\mathrm{Na}$ druhou stranu závažnost přestupku může zvyšovat skutečnost, kde a v jakém čase byl přestupek spáchán a zda byl spáchán opakovaně, místo spáchání přestupku, přítomnost dalších osob či to, zda byla způsobena škoda. ${ }^{31}$ Z uvedeného je tedy zřejmé, že zákonodárce u přitěžujících a polehčujících okolností nedodržuje nastavené odlišování okolností spáchání přestupku od prítěžujících a polehčujících okolností. Správní orgán by v takovém případě měl nejdříve správně roztřídit zjištěné okolnosti, zda spadají pod okolnosti spáchání přestupku, resp. pod kritérium povahy a závažnosti, jež je kritériem základním, a pokud pod uvedené kritérium nelze zkoumanou okolnost zařadit, bude možné k uvedené okolnosti přihlédnout jako k prùitěžující nebo polehčující okolnosti. Důsledně je ale nutné trvat k uplatňování zákazu dvojího přičítání téže okolnosti ze strany správního orgánu.

Okolnosti spáchání přestupku se dělí na subjektivní (týkající se osoby pachatele) a objektivní (týkající se všech ostatních hledisek spáchaného konkrétního přestupku). Mohou to být okolnosti nejrůznějšího druhu, které ovlivňují povahu a závažnost spáchaného přestupku a týkají se místa a času, různých vlivů, jež působily na pachatele při páchání přestupku, dále prostředí, v kterém byl přestupek spáchán, průvodních okolností,

30 Přiměřeně FENYK, J., R. HÁJEK, I. STŘÍŽ a P. POLÁK. Trestni quákoník a trestni rád: priovodce trestnèprávnimi predpisy a judikaturou. 1. díl, Trestní zákoník. Praha: Linde, 2010, s. 238.

31 JEMELKA, L. a P. VETEŠNÍK. Zákon o odpovédnosti za prestupky a ř́reni o nich; Zákon o nékterých prestupcích. 1. vyd. Praha: C. H. Beck, 2017, s. 350-353. 
za nichž k tomu došlo. Jde např. o vliv okolností nezávislých na pachateli, jeho silné rozrušení, tlak závislosti nebo podřizenosti pachatele, vliv hrozby nebo nátlaku, vliv tíživých osobních nebo rodinných poměrů, které si pachatel sám nezpůsobil, spáchání činu při odvracení útoku nebo jiného nebezpečí, aniž byly splněny všechny podmínky okolností vylučujících protiprávnost, spáchání přestupku za krizové situace, živelní pohromy nebo jiné události vážně ohrožující život, veřejný pořádek nebo majetek, anebo na území, na němž je prováděna nebo byla provedena evakuace. Okolnosti spáchání přestupku mohou spočívat též ve spáchání vůči určitým osobám, nap̌r. vưči osobě podílející se na záchraně života a zdraví nebo na ochraně majetku, ke škodě dítěte, osoby blízké, těhotné, nemocné, zdravotně postižené, vysokého věku nebo nemohoucí, dále může jít o svedení k činu jinak trestnému, provinění nebo trestnému činu jiného, zejména dítěte mladšího 15 let, mladistvého apod. ${ }^{32}$

Oproti trestnímu zákoníku přestupkový zákon výslovně neuvádí mezi kritéria při určení druhu a výměry trestu rodinné, majetkové a jiné poměry pachatele - fyzické osoby a dále posouzení jeho dosavadního způsobu života; chování pachatele po činu; to, zda je spolupracující pachatel; k účinkům a důsledkům, které lze očekávat od trestu pro budoucí život pachatele apod. I na tyto skutečnosti by při stanovení druhu a výměry správního trestu měl být brán zřetel, a to i přes to, že oproti trestnímu zákoníku je přestupkový zákon takto explicitně neuvádí. Jejich posouzení proto bude mít význam při zkoumání prritěžujících a polehčujících okolností, nebudou-li tyto okolnosti zohledněny již jako znak skutkové podstaty nebo jako okolnost spáchání přestupku. Tedy nebudou samostatným kritériem při stanovování druhu a výše správního trestu.

V př́padě trestání právnických osob přestupkový zákon oproti zákonu č. 418/2011 Sb. o trestní odpovědnosti právnických osob a řízení proti nim, nestanoví výslovně pro určení druhu a výměry trestu kritéria jako poměry právnické osoby jako celku, kde je povaha její činnosti vedle majetkových poměrů a dalších okolností jen jednou z možností; k působení právnické osoby po činu, zejména k její případné účinné snaze nahradit škodu nebo odstranit jiné škodlivé následky činu; $\mathrm{k}$ účinkům a důsledkům, které lze očekávat od trestu pro budoucí činnost právnické osoby; důsledkům, které může mít uložení správního trestu na třetí osoby, (zájmena osob poškozených a věřitelů právnické osoby, jejichž pohledávky vưči trestně odpovědné právnické osobě vznikly v dobré víre a nesouvisí s přestupkem). I tyto okolnosti mají význam z hlediska stanovení správního trestu, nebot' mohou být posuzovány právě jako přitěžující a polehčující okolnosti, ačkoli je přestupkový zákon výslovně neuvádí mezi samostatná kritéria pro určení druhu a výměry trestu.

32 JELÍNEK, J. a kol. Trestníprávo bmotné. Obecná cást. Zvläštní cást. 6. aktualizované a doplněné vydání. Praha: Leges, 2017, s. 430. 


\section{Význam přitěžujících a polehčujících okolností při ukládání správního trestu}

Předchozí právní úprava přestupků, představovaná vedle zvláštních právních předpisů především zákonem č. 200/1990 Sb. o přestupcích, co do kritérií ukládání sankcí byla spíše strohá oproti právní úpravě obsažené v trestním zákoníku. Jiné správní delikty v tomto směru trpěly ještě více absencí komplexní hmotněprávní i procesní úpravy. Přestupkový zákon oproti této právní úpravě stanoví výčet kritérií, kterými by se správní uvážení o volbě druhu, kombinaci a výměry správního trestu mělo řídit obecně pro dosavadní přestupky, jakož i nové dříve jiné správní delikty, které se dnes řadí rovněž pod přestupky. ${ }^{33} \mathrm{~V}$ důvodové zprávě k PZ zákonodárce uvedl k \37 a \38, Jedná se pouze o demonstrativni výcet okolností, tedy nejenže je možné s obledem na specifika správního trestáni prỉhližet

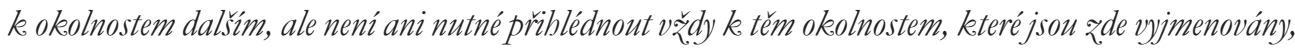
pokud v konkrétnim prípadè nebudou pro posouzeni společenské škodlivosti prestupku roz̧odujicí." "34 Obdobně uvádí důvodová zpráva $\mathrm{k}$ PZ i u přitěžujících a polehčujících okolností, že ani zde není nutné přihlédnout vždy k těm okolnostem, které jsou v zákoně vyjmenovány, pokud v konkrétním případě nebudou pro posouzení společenské škodlivosti přestupku rozhodující. ${ }^{35}$ Uvedenou skutečnost podporuje rovněž uvození „,zejména“, které je vždy v zákonech spojeno s demonstrativním výčtem. Níže proto uvádíme přehledné srovnání právních úprav, kde se zákonodárce inspiroval v trestním zákoníku:

Tab. 1: Srovnání přitěžujících okolnosti PZ a vybraných ustanovení TZ

\begin{tabular}{|c|c|}
\hline Přitěžující okolnosti $\int 40 \mathrm{PZ}$ & Přitěžující okolnosti $\int 42 \mathrm{TZ}$ \\
\hline $\begin{array}{l}\text { \ } 40 \text { písm. a) Využití něčí bezbrannosti, } \\
\text { podř́zenosti nebo závislosti na jiné osobě }\end{array}$ & $\begin{array}{l}\int 42 \text { písm. d) využívaje něčí nouze, tísně, } \\
\text { bezbrannosti, závislosti nebo podř́izenosti }\end{array}$ \\
\hline \ 40 písm. b) spáchal více přestupků & \ 42 písm. n) spáchal více trestných činů \\
\hline \ 40 písm. c) spáchal přestupek opakovaně & \ 42 písm. p) byl již pro trestný čin odsouzen \\
\hline $\begin{array}{l}\int 40 \text { písm. d) zneužil svého zaměstnání, } \\
\text { postavení nebo funkce }\end{array}$ & $\begin{array}{l}\text { ( } 42 \text { písm. f) zneužil svého zaměstnání, } \\
\text { postavení nebo funkce }\end{array}$ \\
\hline $\begin{array}{l}\int 40 \text { písm. e) spáchal přestupek jako člen } \\
\text { organizované skupiny }\end{array}$ & $\begin{array}{l}\text { \ } 42 \text { písm. o) spáchal trestný čin jako } \\
\text { organizátor, člen organizované skupiny, nebo } \\
\text { člen spolčení }\end{array}$ \\
\hline $\begin{array}{l}\text { \ } 40 \text { písm. f) spáchal presestupek na dítěti, } \\
\text { osobě těhotné, nemocné, zdravotně postižené, } \\
\text { vysokého věku nebo nemohoucí }\end{array}$ & $\begin{array}{l}\int 42 \text { písm. h) spáchal přestupek ke škodě } \\
\text { dítěte, osoby blízké, těhotné, nemocné, } \\
\text { zdravotně postižené, vysokého věku nebo } \\
\text { nemohoucí. }\end{array}$ \\
\hline
\end{tabular}

$33 \mathrm{~K}$ definici přestupku podle přestupkového zákona srovnej blíže JEMELKA, L. a P. VETEŠNÍK. Zákon o odpovédnosti za prestupky a ř́zeni o nich. Zákon o některých prestupcích. Komentár. Praha, C. H. Beck, 2017, 1160 s.; PRÁŠKOVÁ, H. Nové prestupkové právo. Praha: Leges, 2017, s. 18.

34 Důvodová zpráva k PZ, s. 168.

35 Ibid. 
Tab. 2: Srovnání polehčujících okolností PZ a vybraných ustanovení TZ

\begin{tabular}{|c|c|}
\hline Polehčující okolnosti \ 39 PZ & Polehčující okolnosti $\int 41$ TZ \\
\hline $\begin{array}{l}\int 39 \text { písm. a) spáchal přestupek ve věku } \\
\text { blízkém mladistvému }\end{array}$ & $\begin{array}{l}\int 41 \text { písm. f) spáchal trestný čin ve věku } \\
\text { blízkém mladistvému }\end{array}$ \\
\hline $\begin{array}{l}\int 39 \text { písm. b) aby odvrátil útok nebo jiné } \\
\text { nebezpečí, aniž byly zcela naplněny podmínky } \\
\text { nutné obrany, krajní nouze, nebo překročil } \\
\text { meze jiné okolnosti vylučující protiprávnost }\end{array}$ & $\begin{array}{l}\int 41 \text { písm. g) odvraceje útok nebo jiné } \\
\text { nebezpećí, aniž byly zcela naplněny podmínky } \\
\text { nutné obrany, krajní nouze, nebo překročil } \\
\text { meze jiné okolnosti }\end{array}$ \\
\hline $\begin{array}{l}\text { 〔 } 39 \text { písm. c) napomáhal k odstranění } \\
\text { škodlivého následku přestupku nebo } \\
\text { dobrovolně nahradil způsobenou škodu }\end{array}$ & $\begin{array}{l}\int 41 \text { písm. j) přičinil se k odstranění } \\
\text { škodlivých následku trestného činu nebo } \\
\text { dobrovolně nahradil způsobenou škodu }\end{array}$ \\
\hline $\begin{array}{l}\int 39 \text { písm. d) oznámil přestupek a při jeho } \\
\text { objasňování účinně napomáhal }\end{array}$ & 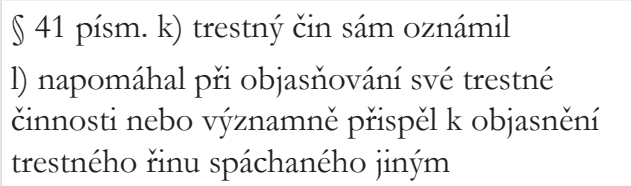 \\
\hline $\begin{array}{l}\text { \ } 39 \text { písm. e) spáchal přestupek pod } \\
\text { vlivem hrozby, nátlaku anebo pod tlakem } \\
\text { podř́izenosti nebo závislosti }\end{array}$ & $\begin{array}{l}\int 41 \text { písm. c) spáchal TČ pod tlakem } \\
\text { podř́zenosti nebo závislosti } \\
\text { d) pod vlivem hrozby nebo, nátlaku }\end{array}$ \\
\hline
\end{tabular}

Přitěžující a polehčující okolnosti se řadí mezi okolnosti významné pro stanovení druhu a výměry trestu, které se pravidelně uplatní vedle dalších okolností stanovených v \37 PZ ${ }^{36}$, resp. stanovených zvláštními předpisy. Oproti trestnímu zákoníku, který v \39 odst. $4^{37}$ stanoví obecně známý princip zákazu dvojího přičítání z hlediska viny a z hlediska trestu, PZ výslovně takovéto ustanovení nemá. Není zcela patrné, z jakého důvodu zákonodárce obdobné ustanovení do přestupkového zákona nevložil, ale i přes zmíněnou absenci v zákoně, je nutné, aby správní orgán uvedenou zásadu při uvážení o ukládání správních trestů respektoval. ${ }^{38,39}$

36 Ustanovení \ 37 PZ stanoví uvedená kritéria: 1) povaha a závažnost přestupku 2) nebylo rozhodnuto ve společném řízení, 3) přitěžující a polehčující okolnosti 3) u pokusu pak přiblížení se k dokonání a související okolnosti, 4) u spolupachatelů míra přispění, 5) u fyzických osob k osobním poměrům, 6) u právnických osob a fyzických osob podnikajících $\mathrm{k}$ povaze jejich činnosti, u právního nástupce $\mathrm{k}$ rozsahu přenesených, výnosů, užitků a jiných výhod.

37 Ustanovení \ 39 odst. 4 TZ k okolnosti, která je zákonným znakem TČ, vč. Okolnosti, která podmiňuje vyšši sazbu nelze přihlédnout jako k polehčující nebo jako k přetěžující okolnosti z hlediska ukládaného druhu a výměry trestu.

38 Výjimkami je, pokud uvedená okolnost je již znakem správního deliktu v jeho základní př́padně kvalifikované skutkové podstatě. Opačný postup by byl v rozporu se zásadou zákazu dvojího přičítání z hlediska viny a následně z hlediska trestu. Není ovšem vyloučeno, aby správní orgán přihlédl intenzitě naplnění této okolnosti (nap̌r. k výši škody přesahujíc zákonem stanovený požadavek, k míre zavinění, intenzitě trestního jednání a tím způsobeného následku, tedy k uvedeným kvantitativním znakům).

39 Tento požadavek se dovozuje mj. i z výkladu čl. 6 Evropské úmluvy o ochraně lidských práv a svobod a navazující ustálené judikatury jako součást spravedlivého procesu a realizace obecné zásady ne bis in idem. 
Z důvodové zprávy k PZ se na první pohled může zdát, že správní orgán se s uvedenými zákonnými kritérii nemusí ve svém odůvodnění rozhodnutí o uložení správního trestu vypořádat vi̊bec, pokud nebudou podle jeho názoru v daném případě rozhodující pro posouzení přestupku. Tomu odpovídá i postup soudů, které při soudním trestání neodůvodňují ne/aplikaci každé zákonem stanovené přitěžující nebo polehčující okolnosti, ale vypořádávají se pouze s těmi, které jsou pro daný př́pad relevantní. Trestním zákoníkem stanovený výčet stanoví základní okolnosti, jež mohou a nemusí být významné pro posouzení společenské škodlivosti a pro zohlednění individuality konkrétního případu při ukládání trestů. Je proto na soudu, aby zohlednil všechny pro případ významné přitěžující a polehčující okolnosti. K povinnosti správního orgánu vypořádávat se se všemi přitěžujícími a polehčujícími okolnostmi stanovenými v zákoně se vyjádřil J. Potměšil, který poukazuje, že lpění na nutnosti vypořádat se se všemi zákonem výslovně uvedenými hledisky by mohlo vést k odklonu od požadované transparentnosti ukládání sankcí. ${ }^{40}$ Zde se ale dostáváme do jisté kolize s dosavadní judikaturou správních soudů, která vyžaduje, aby zákonem stanovená kritéria ${ }^{41}$ byla v odůvodnění zohledně$\mathrm{na},{ }^{42}$ a důvodové zprávy $\mathrm{k}$ PZ, kde zákonodárce uvedl, že se nemusí vždy k uvedeným kritériím přihlédnout. I přes to, že důvodovou zprávu $\mathrm{k}$ PZ nemůžeme řadit mezi formální prameny práva, jedná se o vodítko $\mathrm{k}$ podpůrnému výkladu nové právní úpravy. ${ }^{43}$ Zde musím souhlasit s J. Potměšilem, že trvat na povinnosti přihlížet a zdůvodnit nepoužití všech zákonem výslovně stanovených okolností (i těch, které jsou v daném př́padě $z$ logiky věci nemyslitelné), může být rizikové a vést $\mathrm{k}$ nežádoucímu zahlcování správních orgánů. Není v obecném zájmu, aby požadavek důsledného odůvodnění z povahy věci neaplikovatelných vedl k nežádoucímu vytváření „biče na veréjnou správu“ a její rozhodnutí by mohla být napadána pro nezákonnost s odkazem na to, že to či ono dílčí hledisko nebylo v odůvodnění zohledněno. ${ }^{44}$ Uvedené ale nezbavuje správní orgán povinnosti zabývat se všemi rozhodnými okolnostmi, a to i okolnostmi v zákoně neuvedenými. V této souvislosti musím poukázat, že vytváření demonstrativních výčtů okolností v zákonech, které navíc nejsou aplikovatelné pro všechny správní delikty, povede k rozšíření možností, kde správní orgán může udělat chybu v odůvodnění svého rozhodnutí například z důvodu opomenutí některé aplikovatelné okolnosti, což v důsledku povede k nepřezkoumatelnosti, resp. k nezákonnosti takového rozhodnutí.

40 POTMĚŠIL, J. Poznámky k věcnému záměru nového zákona o přestupcích. Správní právo, 2014, roč. XLVII, č. 1-2, s. 127.

41 S přihlédnutím k PZ zvláště i pokud není umožněna diskrece správnímu orgánu ve smyslu „může přihlédnout“, ale prrímo autoritativně uvádí, že „se přihlédne“ může tato otázka v praxi činit problém.

42 Srovnej rozsudek Nejvyššího správního soudu ze dne 31. 3. 2004, č.j. 5 A 154/2002-51.

43 K problematice postavení důvodové zprávy srovnej: nález Ústavního soudu ze dne 19. 11. 2013, č. j. II. ÚS 4754/12. Dostupné z: http:/ /www.nalus.cz

44 POTMĚŠIL, J. Poznámky k věcnému záměru nového zákona o přestupcích. Správní právo, 2014, roč. XLVII, č. 1-2, s. 126-127. 
Zákonodárce se při sestavování zákonem uvedených přitěžující a polehčujících okolností silně inspiroval v TZ ${ }^{45}$. U nově zákonem výslovně uvedených přitěžujících okolností si nyní pozornost zaslouží \ 40 písm. c) PZ ,prestupek spáchal opakovaně“. Z jazykového výkladu uvedeného ustanovení není zcela zřejmé, zda se jím myslí jakýkoli přestupek (a to i přestupek chránící zcela odlišný veřejný zájem), nebo je tím myšlena recidiva u zcela totožného skutku. Uvedené posuzování recidivy může v praxi správních orgánů přinášet nemalé potíže. Osobně se domnívám, že by z logiky věci neměly být posuzovány veškeré spáchané přestupky, nebot' uvedený postup by byl nepřiměřeně přísný $\mathrm{v}$ rozporu se subsidiaritou trestní represe a dále by byl v rozporu s právní jistotou. Zároveň by posouzení nemuselo být nutně omezováno pouze na zcela totožný přestupek tak, aby právní úprava umožňovala posuzovat recidivu i u přestupků chránící tentýž veřejný zájem. Rovněž je třeba upozornit, že za opakované (tedy obecně nejméně dvakrát) se považuje i trvající nedodržování právních předpisů, pokračuje-li i po neformálním upozornění ze strany správního orgánu (nap̌r. nekonání tam, kde je povinnost konat). ${ }^{46} \mathrm{~V}$ této souvislosti je navíc nutné poukázat na zvláštní recidivu dle \13 zákona č. 251/2016 Sb., o některých přestupcích ${ }^{47}$, který pro vybrané přestupky definuje opakované spáchání přestupku, takže přestupek je spáchán opakovaně, pokud po nabytí právní moci rozhodnutí o stejném přestupku, z něhož byl obviněný uznán vinným, do jeho spáchání neuplynulo 12 měsíců. Současně je nutné rozlišovat recidivu jako obecnou přitěžující okolnost a vedle recidivu zakládající důvod pro zvýšení horní hranice sazby pokuty, tam, kde to stanoví zvláštní zákon, kdy z důvodu zákazu dvojího přičítání téže okolnosti, nemůže být recidiva posuzována současně jako přitěžující okolnost.

Další otázkou, která se může u této okolnosti nabízet, je, zda může správní orgán přihlédnout $\mathrm{k}$ této přitěžující okolnosti i v případech, kdy předmětný správní delikt byl $\mathrm{v}$ minulosti označen jako jiný správní delikt? V této souvislosti budou rozhodující přechodná ustanovení, zejména $\int 112$ odst. 1 PZ, podle kterého se na přestupky a dosavadní jiné správní delikty, s výjimkou disciplinárních deliktů, ode dne nabytí účinnosti přestupkového zákona hledí jako na přestupky. Rovněž je důležité upozornit i na skutečnost, že pokud by byla recidiva znakem skutkové podstaty, nesmí k ní správní orgán pruihlížet, nebot' v opačném př́padě by docházelo k porušení principu zákazu dvojího přičítání. ${ }^{48}$

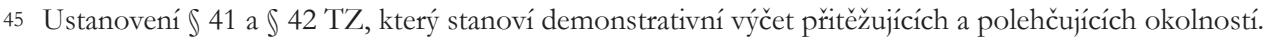

46 Srovnej: RUBEŠ, P. Zákon o vodovodech a kanalizacích. Komentár. 1. vyd. Praha: Wolters Kluwer, 2014, s. 284.

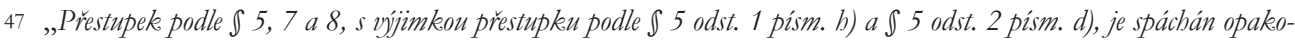
vanè, jestliže od nabyti právni moci rozhodnuti o stejném prestupku, z nèhož byl obvinèný uznán vinným, do jeho spáchání neuplynulo 12 mèsícü. "

$48 \mathrm{~V}$ případě zákazu dvojího přičítání se jedná o otázku rozlišování (odstupňování) intenzity nezbytné k naplnění skutkové podstaty ne jedné straně a intenzity další (vyšší, z hlediska naplnění skutkové podstaty nevyčerpané), která teprve mưže mít význam z hlediska úvah o trestu jako okolnosti přitěžující a polehčující. Srovnej rozsudek Nejvyššího správního soudu ze dne 29. 8. 2012, č. j. 4 Ads 114/2011-105. 
Vzhledem $\mathrm{k}$ inspiraci některých znění přitěžujících a polehčujících okolností v trestním zákoníku, nabízí se rovněž poukázat i na významné závěry, které se rovněž uplatnî i v přestupkovém právu. První závěr se vztahuje k otázce obsahu prítěžujících a polehčujících okolností, který se může bud’ vztahovat k následku nebo účinku trestného činu (přestupku), ke způsobu jednání, k osobě pachatele, k subjektivní stránce trestného činu (přestupku) a k jeho pohnutce, nebo k jiné skutečnosti a některé z nich se navíc mohou prolínat. $^{49}$

Dalším postřehem u přitěžujících okolností oproti trestnímu zákoníku je zúžení kritéria závislosti dle $\int 40$ písm. a) PZ pouze jako závislosti na jiné osobě. Znamená to, že by nemělo být zohledňováno využití závislosti na lécích či drogách jako je tomu dle \ 42 písm. d) TZ, když ji zákonodárce výslovně neuvádí, nebo tím, že uvedené okolnosti jsou pouze demonstrativní, může k nim správní orgán přihlédnout? Zde se domnívám, že uvedená úprava nevylučuje možnost k této okolnosti přihlédnout jako k jiné zákonem výslovně neuvedené přitěžující okolnosti, zvláště pokud komentářová literatura potvrzuje zkoumání bezbrannosti jako stavu, který může nastat mj. i jako důsledek bezvědomí $z$ důvodu opilosti nebo jiného podobného opojení atd..$^{50}$ Další změnou oproti úpravě v TZ je, že dle $\int 40$ písm. f) PZ mưže být uvedená okolnost posouzena, pokud by byl přestupek spáchán př́imo „na osobě“ (dítěti, těhotné, nemocné, zdravotně postižené, vysokého věku nebo nemohoucî). Jedná se o odlišné kritérium oproti ustanovení \42 písm. h) TZ, kde má být posuzováno, zda byl trestný čin spáchán „ke škodě“ těchto osob, tj. na její úkor, a to jak ke škodě v materiálním smyslu, tak i jakoukoli další újmu jak majetkovou tak i nemajetkovou. ${ }^{51} \mathrm{~V}$ přestupkovém řízení nebude tedy nutné zkoumat, zdali vznikla škoda. Na druhou stranu požadavek zásahu do integrity osoby může uvedené kritérium omezovat naopak nežádoucím způsobem. S ohledem na demonstrativnost přitěžujících okolností není vyloučeno, že správní orgán mưže zvlášt' přihlédnout i ke skutečnosti, zda škoda vznikla, musí ale zásadně v odůvodnění svého rozhodnutí důsledně odlišit uvedenou okolnost od zmíněné přitěžující okolnosti, aby nedoházelo ke dvojímu přičítání z hlediska viny nebo ukládaného trestu.

Z hlediska polehčujících okolností se zákonodárce inspiroval v TZ a rovněž zde dochází k nepatrným rozdílům. Zde si zaslouží pozornost \39 písm. d) PZ, které stanoví jako polehčující okolnost skutečnost, že pachatel „oznámil prestupek a pru jeho objasnováni účnně napomáhal“. Jedná se o kumulativní spojení dvou dílčích podmínek, které

49 ŠÁMAL, Pavel a kol. Trestní zákoník. Komentár. 2. vyd. Praha: C. H. Beck, 2012, s. 541. Dostupné z: http:// www.beck-online.cz

50 VETEŠNÍK, P. In: JEMELKA, L. a P. VETEŠNÍK. Zákon o odpovédnosti qa presstupkey a rǐzení o nich. Zákon o něketerých presstupcích. Komentár. Praha, C. H. Beck, 2017, s. 366.

51 Komentář v této souvislosti uvádí, že čin musí být spáchán ke škodě, tj. na úkor zákonem charakterizované oběti. Nejde zde ovšem o škodu v materiálním smyslu, která má význam jako znak trestného činu, či je možné ji požadovat v adhezním řízení, ale jedná se o jakoukoli další újmu jak majetkovou, tak nemajetkovou. Srovnej. PÚRY, F. In: ŠÁMAL, Pavel a kol. Trestni zákoník. Komentár. 2. vyd. Praha: C. H. Beck, 2012, s. 562. 
musí být naplněny, aby je správní orgán při určení správního trestu zohlednil. Oproti tomu u soudního trestání, kde jsou uvedené okolnosti stanoveny v TZ samostatně pod 〔 41 písm. k) a l) na sobě vzájemně nezávisle a jedná se o dvě samostatné polehčující okolnosti. Pokud by obviněný přestupek oznámil, ale následně nenapomáhal objasnění, nemělo by to dle PZ umožňovat zohlednit tuto jinak polehčující okolnost.

Jak je na základě uvedeného patrné, mohou výslovně uvedené okolnosti v praxi přinášet obtíže zejména pro správní orgány a následně pro správní soudy při kontrole jejich rozhodnutí. Vedle zákonem uvedených přitěžujících a polehčujících okolností mohou mít pro rozhodovací praxi svůj nemalý význam i okolnosti posuzované v soudní judikatuře. Z hlediska aktuální judikatury je možné poukázat na rozhodnutí Krajského soudu v Plzni, který jako logickou úvahu posoudil, že porušení povinností vedoucími zaměstnanci nemá být polehčující okolností, nebot' výběr vedoucích pracovníků je volbou prrímo potrestané právnické osoby, a tudíž se jí nelze dovolávat. I přes uvedenou premisu ale fakticky vzato došlo ze strany správního orgánu k posouzení chování těchto zaměstnanců při podílení se a tolerování porušování předpisů jako mírně polehčující okolnosti. Stejným způsobem pak bylo posouzeno i nastavení kontrolních mechanismů a organizační struktura společnosti. ${ }^{52}$ Naopak shodný soud jako k polehčující okolnosti přihlédl k tomu, že účastník řízení přijal nápravná opatření a zavedl či zavádí na svých provozovnách nový systém evidence a kontroly omezující spáchání správního deliktu.

Z rozhodovací praxe soudů dále stojí za zmínku i rozhodnutí, které trvající správní delikt a vědomé systémové neplnění povinností považuje za přitěžující okolnosti. ${ }^{53}$ Rovněž by bylo jako přitěžující kritérium hodnoceno, zda se pachatel dopouštěl jednání delší dobu nebo zda se téhož přestupku dopustil opakovaně. ${ }^{54}$

Z hlediska odůvodnění výše a přiměřenosti trestu v návaznosti na (ne)zjištěné polehčující okolnosti je zcela zásadní i část odůvodnění publikovaná ve sbírce rozhodnutí Nejvyššího správního soudu, kde se uvádí, že i při ,zcela jednoznačně zjiš̌těných a v odivvodnèní roz̧odnutí popsaných prìtě̌zujicich okolností nebyla žalobci uložena pokuta ani v jedné desetině horni branice stanovené sazby..., což svědči jednoznačně o tom, že správni úrady obou stupño rádné a úplně posoudily i polebčujicí okolnosti a neuložily žalobci pokutu ve zjevnè neprimèrené výši. "55 Z uvedeného rozhodnutí vyplývá, že u pokut uložených při dolní hranici by snad měly být dány menší nároky na identifikaci ve věci veškerých významných polehčujících okolností. Uvedená judikatura by ale neměla zakládat pasivitu správního orgánu při vlastním vyhledávání přitěžujících a polehčujících okolností ani pokud ukládá pokutu při dolní hranici sazby. Neustále je nutné mít na paměti, že rozhodnutí má být nejen zákonné,

52 Srovnej rozsudek Krajského v Plzni ze dne 24. 5. 2017, sp. zn. 30 A 124/2015.

53 Srovnej rozsudek Krajského soudu v Českých Budějovicích ze dne 27. 3. 2017, č. j. 10 Af 10/2016-58.

54 Srovnej rozsudek Nejvyšší správní soud ze dne 16. 4. 2013, č. j. 6As 74/2012-21.

55 Rozsudek Městského soudu v Praze ze dne 4. 6. 2014, č. j. 11 Ad 16/2013-41. 
ale i individualizované, přičemž odůvodnění by mělo po odvolání působit přesvědčivě tak, aby se ze správního soudnictví nestával (dalšî) třetí stupeň.

\section{Závěr}

Osobně vnímám přestupkový zákon jako přínos pro správní trestání, a i přes uvedené dílčí výhrady, se jedná o posun vpřed. Zde si jen dovolím nastínit své obavy z nadměrného přebírání institutů trestního práva, které mohou namísto zpřehlednění činnosti veřejné správy při ukládání správních trestů vést ke zpomalení nebo až k ochromení efektivní činnosti. Obecně platí, že v jednoduchosti je síla. Př́liš mnoho převzatých institutů z trestního práva do správního ř́izení, nejenže nemusí být př́inosem ani pro subjektivní práva účastníka na zabezpečení práva na spravedlivý proces, ale může vést k obtížím při rozhodování správních orgánů. Jasně nastavená a jednoduchá pravidla pro delikventy jsou zpravidla vhodnější i z hlediska generální i individuální prevence.

V otázce rámce správního uvážení při ukládání správního trestu je patrné, že zákonodárce výslovným rozšířením kritérií $\mathrm{v}$ zákoně má zájem na upřesnění rámce správního uvážení při ukládání trestu. Zároveň skrze demonstrativnost uvedených kritérií dává správnímu orgánu možnost zohlednit vždy individuálnost každého př́padu. $\mathrm{Na}$ druhou stranu zákonodárce nedrží nastavené systematické rozdělení, což může působit matoucím dojmem. Ve vztahu k výslovně uvedeným kritériím vyvstávají některé sporné otázky, které se v praxi mohou ukázat jako problematické. Zákonodárce tak možná nevědomky vytvořil pro správní orgán minové pole, kdy se správní orgány budou muset mít více než kdy dříve na pozoru. Současně v přestupkovém zákoně vymezené přitěžující a polehčující okolnosti nejsou okolnostmi, které by byly aplikovatelné na většinu případi̊, resp. škála přestupků je natolik rozmanitá, že to ani není možné. Na základě úvah de lege ferenda mám za to, že by bylo vhodnější tyto demonstrativní výčty okolností ze zákona zcela vypustit a nechat posouzení přitěžujících a polehčujících okolností na uvážení správního orgánu v konkrétním daném případě. 